原発性肝癌に招ける超音波誘導下経皮経肝門脈造影像

\begin{tabular}{cccccc}
\multicolumn{5}{c}{ 大阪市立大学第2外科 } \\
井川 & 澄人 & 木下 & 博明 & 井上 & 直 \\
松岡 & 修二 & 長田 & 栄一 & 鈴木 & 範男 \\
李 & 東雨 & 村松 & 秀幸 & 街 & 保敏 \\
広橋 & 一裕 & 成山多喜男 & 酒井 & 克治 \\
ULTRASONDCALLY GUIDED PERCUTANEOUS TRANSHEPATIC \\
PORTOGRAM IN PRIMARY CARCINOMA OF THE LIVER \\
Sumito IGAWA, Hiroaki KINOSHITA, Tadashi INOUE, Shuji MATSUOKA \\
Eiichi NAGATA, Norio SUZUKI, Tou RYE, Hideyuki MURAMATSU \\
Yasutoshi TUJI, Kazuhiro HIROHASHI, Takio NARUYAMA and Katsuji SAKAI
\end{tabular}

The 2nd Department of Surgery, Osaka City University Medical School

原発性肝癌12例（肝細胞癌11例，胆管細胞癌 1 例）の術前に超音波誘導下経皮経肝門脈造影（以下 超音波下 PTP) を施行し，その造影所見について検討した。 その結果右後枝分㿬異常 3 例，尾状葉枝 が10例で確認された。肝内門脈枝の先細り閉塞像 7 例, 陰影欠損像 3 例, 肝内門脈枝の王排像 5 例, 側副血行路 2 例が観察された。 また切除標本から門脈枝の先細り閉塞像は腫瘍による単なる圧迫閉塞 であり，陰影欠損像は門脈内腫瘍塞栓であることが判明した。

PTP は肝内門脈枝を鮮明に描出するため腫湯塞栓の診断, 覀区域切除における切除門脈枝の決定, さらには肝門部剥離操作に有力な情報を提供すると考えられる。

索引用語：原発性肝癌, 超音波下経皮経肝門脈造影, 門脈分岐異常, 門脈塞栓の診断, 肝区域切除

\begin{abstract}
緒言
近年各種画像診断装置の開発・普及や生化学的検査 の励行により, 原発性肝癌の診断技術は著しく向上し, 細小肝癌もかなり発見されるようになった その治療成績は他の消化器癌に比べてきわめて不良 で，たとえ切除しえても再発によって死亡するものが 多( ${ }^{2)}$. その原因として原発性肝癌は肝硬変を高頻度 に合併することの注かに, 早期から肝内門脈枝に腫煬 塞栓を形成するためであるといわれている3).した がって肝癌症例の術前に腫瘍の肝内門脈枝への影響や 門脈分岐状態を正確に把握しておくことは切除範曲の 決定とその手術操作にきわめて重要である。そこで原 発性肝癌例に対して超音波下 PTPを施行し, それら の所見を肝切除標本と対比し, 肝切除時における超音 波下 PTP の有用性について検討を加えた。
\end{abstract}

\section{I 対象症例}

対象症例は昭和 55 年 7 月から昭和 57 年 1 月までに当 科に入院した肝細胞癌 11 例, 胆管細胞癌 1 例の計 12 例
である.その性別は男女ともに各 6 例. 年齢は 46 歳 68 歳，平均年龄は 57.3 歳であった。な括腫瘍の占拠部位 を動脈造影所見扣よびCT 像から判断すると表 1 に示 すと拈りであった。

\section{II 方 法}

1. 超音波下 PTP 法

リニア型電子スキャン東芝製 SAL一30A を用いて あらかじめ肝癌の局在部位, 門脈脐部, 肝静脈および

表 1 PTPが施行された原発性肝癌症例

\begin{tabular}{|c|c|}
\hline 肝細胞摛 & 11 \\
\hline 右後上亜区域 & 3 \\
\hline 右後下亜区域 & 2 \\
\hline 右前上垔区域 & 2 \\
\hline 右前上亚区域と内側区域 & 2 \\
\hline 左外側下亚区域 & 1 \\
\hline 右後下亜区域と後上脛区域 & 1 \\
\hline 胆管細盷癌 左三区域 & 1 \\
\hline
\end{tabular}

数字は症列数 
図 1 超音波下 PTP 用器具とカテーテルの㨀入法 図左：超音波下 PTP 用器具

図中：左門脈脐部（上）と同部より插入されたカテーテル

図右：右門脈枝（上）と同部より插入されたカテーテル
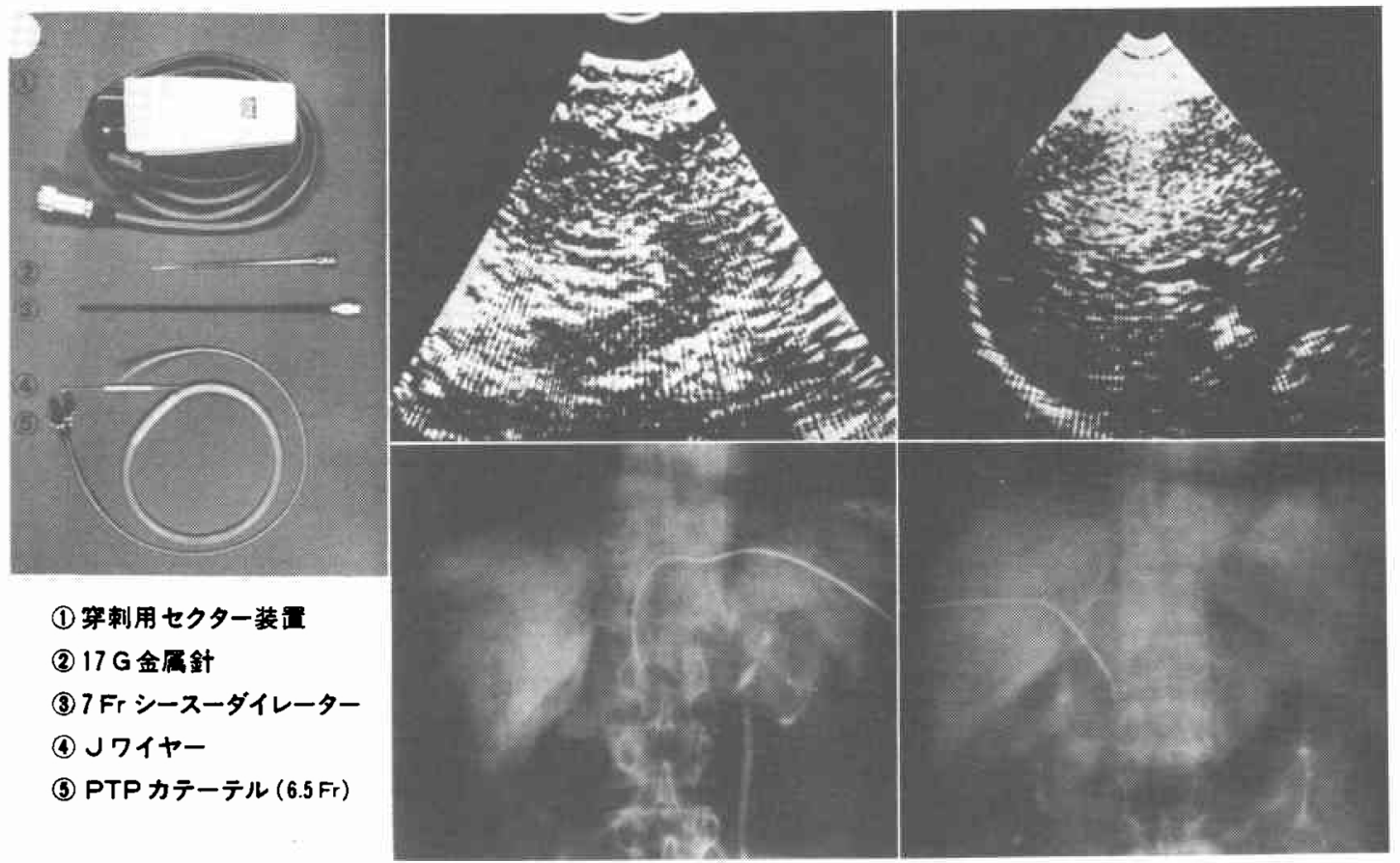

門脈第 1 分枝の腫瘍塞栓の有無について検索し, 穿刺 門脈枝を決定して扰く. PTP 施行当日は, 約 6 時間前 から絶食させ，1時間前に鎮静剂と硫酸フトロピンを 筋注する。すずメカニカルセクター式アロカ社製 SSD - 115 誘導下に八光社製 $17 \mathrm{G}$ 金属針を用いて門脈左枝 脐部あるいは右枝を穿刺する。ついで Seldinger 法に 準じてCook 社製カテーテル $(6.5 \mathrm{Fr})$ を門脈本幹内に すすめて $76 \%$ ウグラフィン $40 \mathrm{ml} を 15 \mathrm{ml} /$ 秒で圧入, 秒 3 枚を正側面で交互に連続撮影し, 必要に応じて第 1 斜位の撮影を追加した(図 1). PTP 終了後, カテー テルの先端を肝実質内に15分間留置したのちカテーテ ルを抜去する。な提例によってはカテーテル拔去に 際して肝実質内にゼラチンスポンジを留置し, 肝穿刺 孔からの腹腔内出血を防止した4).

2. 経皮経肝門脈造影像の読影

PTP の読影には門脈本幹からの門脈枝の分岐状態, 尾状葉枝の確認, 肝内門脈第 $1 \sim 4$ 分枝の閉塞, 王排 おょび陰影欠損像の有無, sinusoidal phase での陰影 欠損おょび門脈側副血行路の有無について検討した。

\section{III. 結 果}

門脈の穿刺部位は門脈左枝脐部が 9 例, 門脈右枝が 3 例で, 穿刺回数は $1 \sim 3$ 回, 平均 1.4 回で, 超音波下 PTP 施行の全例に肝内門脈枝の分岐状態が経動脈性 門脈造影に比べて明暸に描出した。 12例中 3 例 (25\%) には門脈幹から直接分岐する右後枝の分岐異常が明ら かになり，10例（83\%）に左右の門脈第 1 分枝から分 岐する尾状葉枝が確認された。 また門脈 1 次, 3 次, 4 次分枝の閉塞がそれぞれ 1 例， 4 例および 2 例にみ られ，肝切除の行われた 5 例ではこれらはいずれる腫 瘍による単なる圧迫閉塞であることが確認された。さ らにこれら症例の sinusoidal phase では腫婸部は陰影 欠損となっていた。 また肝内門脈枝の陰影欠損像が 3 例（左 1 次分枝之 2 次分枝 1 例, 右 2 次分枝 1 例, 右 3 次分枝 1 例）に認められ，そのうちの 2 例は切除標 本から同部における門脈内腫瘍塞栓であることが確認 された，次いで腫瘍による1次，2次， 3 次分枝の王 排像がそれぞれ 1 例， 3 例， 3 例に，側副血行路の発 達が 2 例隹められた（表 2 ）。

な怙本法の合併症として腹腔内出血・胆汁漏出など 
表 2 原発珄肝癌12例の PTP 所見

\begin{tabular}{|c|c|}
\hline 右後枝の分岐異常 & 3 \\
\hline 尾状葉枝の分岥 & 10 \\
\hline 肝内門脈枝の閉塞 & 7 \\
\hline 1 次分枝 & 1 \\
\hline 2 次分枝 & 0 \\
\hline 3 次分枝 & 4 \\
\hline 4 次分枝 & 2 \\
\hline 肝内門脈枝の圧排 & 5 \\
\hline 1 次分枝 & 1 \\
\hline 2 次分枝 & 3 \\
\hline 3 次分枝 & 3 \\
\hline 門脈內陰影欠損像 & 3 \\
\hline 1 次分枝 & 1 \\
\hline 2 次分枝 & 2 \\
\hline 3 次分枝 & 1 \\
\hline 側副血行路の発達 & 2 \\
\hline
\end{tabular}

図 2 症例 1 の血管造影像

A. 腹腔動脈造影像：右肝動脈が著明に払張し, その末梢に腫瘍血管と tumor stain が認められる.

B. 経動脈性門脈像

C, D. PTP：尾状葉枝（cの矢印）と側副血行路（Dの矢印）が描出されている.

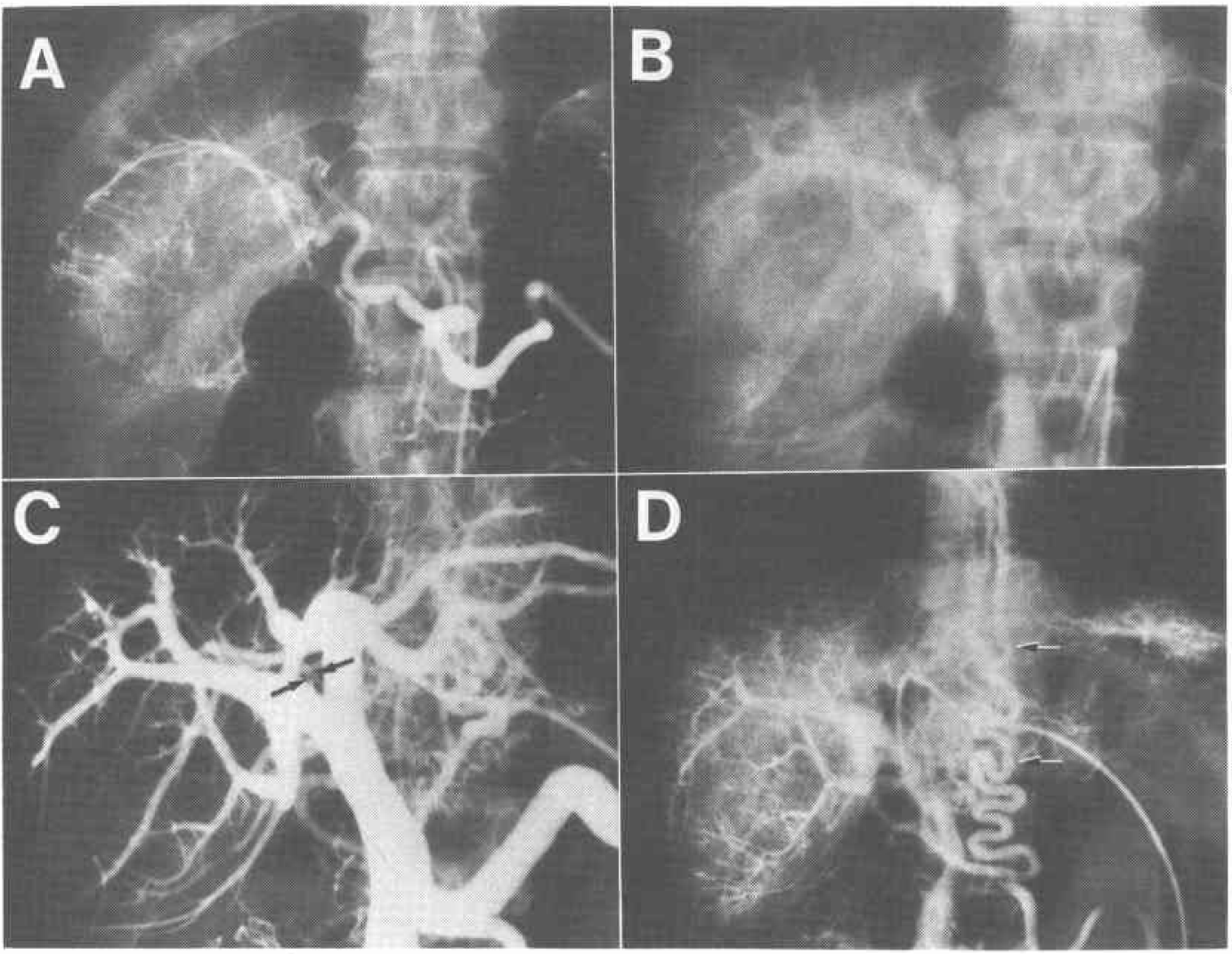


枝の分岐状態之側副血行路の発達が経動脈性門脈造影 に比べて鮮明に造影された(図 2 ). 以上の検査所見か ら手術不能と判断された。

症例 2.57歳, 男, タクシー運転手.

昭和 54 年 4 月の健康診断で高血圧と慢性肝炎を指摘 された。昭和56年初旬より右季肋部痛が出現し，AFP 值の上昇と肝シンチ拉よび超音波検査の結果, 左内側 区域，右前区域の Hepatoma が疑われた。 入院時検査 では, WBC $2,600 / \mathrm{mm}^{3}, \mathrm{RBC} 394 \times 10^{4} / \mathrm{mm}^{3}, \mathrm{Hb} 13.2$ $\mathrm{g} / \mathrm{dl}, \mathrm{Ht} 40.7 \%$, 血小板 $6.8 \times 10^{4} / \mathrm{mm}^{3}$, 出血時間 3 分, 凝固時間 8 分 30 秒, Prothrombin time $98 \%$, Hepaplastin test $60 \%$, TP $7.1 \mathrm{~g} / \mathrm{dl}$ (alb $3.2 \mathrm{~g} / \mathrm{dl}, \boldsymbol{\gamma}$-gl $31.3 \%$ ), TTT $5.8 \mathrm{U}$, ZTT $20.0 \mathrm{U}$, T-Bil $0.9 \mathrm{mg} / \mathrm{dl}$, GOT 195IU, GPT $161 \mathrm{IU}$, Che $0.33 \triangle \mathrm{ph}$, Alp 18.8 $\mathrm{KAU}$, AFP $36,440 \mathrm{ng} / \mathrm{ml}$, ICG Rmax $2.5 \mathrm{mg} / \mathrm{kg} / \mathrm{min}$
であった。

肝動脈造影像で中央二区域にまたがる腫瘍濃染像が あり, thread and streaks sign を認めた。経動脈性門 脈造影像では左第 1 分枝内の filling defectが疑われ， PTP を行うと左第 1 分枝内に明らかな腫瘍塞栓像と 内側枝・尾状葉枝の圧排像が明暸に認められ（図 3 ), 肝切除の適応外と判断された。

症例 3.68 歳, 男, 無職。

約 6 力月前より食後心窩部痛があり，超音波検查， 肝シンチ像から右葉後区域のSOLを指摘され当院第 3 内科から当科へ転入した。理学的に右鎖骨中線で肝 を 3 横指触知する以外異常が認められなかった。入院 時検査では, WBC $5,400 / \mathrm{mm}^{3}, \mathrm{RBC} 391 \times 10^{4} / \mathrm{mm}^{3}$, $\mathrm{Hb} 13.2 \mathrm{~g} / \mathrm{dl}, \mathrm{Ht} 38.9 \%$, 血小板 $21.9 \times 10^{4} / \mathrm{mm}^{3}$, 出血 時間 5 分，凝固時間 8 分，Prothrombin time $150 \%$,

図 3 症例 2 の血管造影像

A. 腹腔動脈造影像：右前区域, 左内側区域の腫場濃染像と thread and streaks sign （矢印）を認める。

B. 経動脈性門脈造影像：矢印に filling defect が疑われる.

C, D. PTP : 左 1，2 次分枝に filling defect（大矢印）と，尾状葉枝（小矢印），内 側枝の王排像を認める。

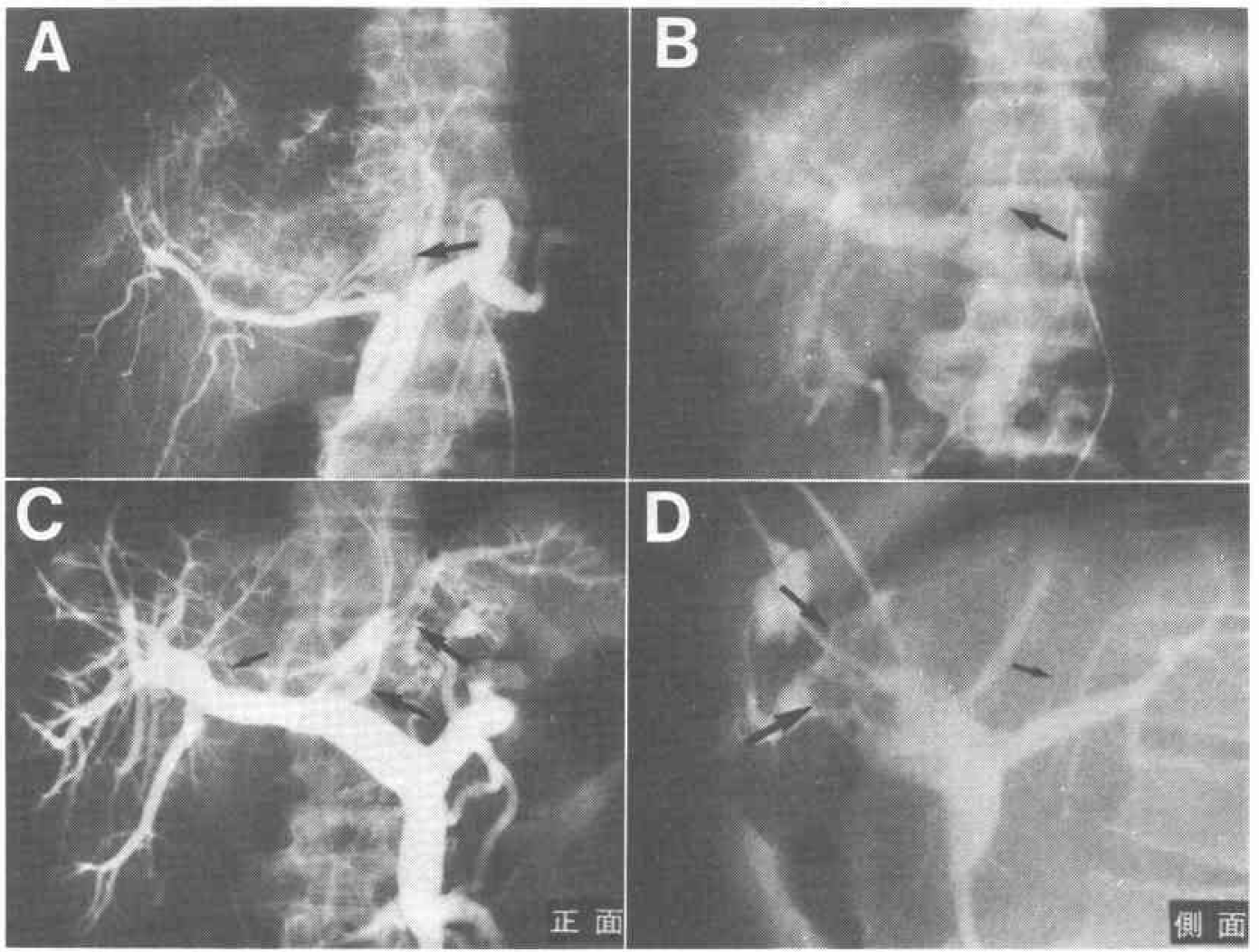


図 4 症例 3 の血管造影像

上：総肝動脈造影像：右後下覀区域に腫瘍血管之 tumor stain 認め, 右後上亜区域枝の末梢に为 tumor stain を認める.

下；動脈性門脈造影像：門脈右後枝の描出が不明暸で ある。

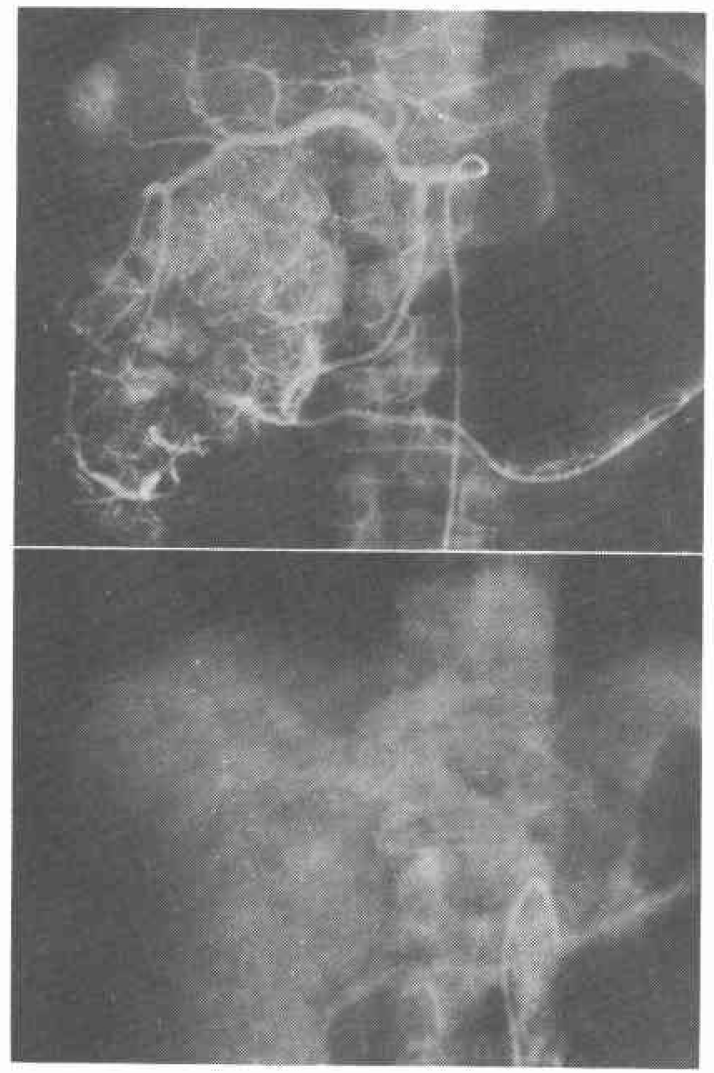

Hepaplastin test $117 \%$, TP $7.0 \mathrm{~g} / \mathrm{dl}$ (Alb 3.2g/dl, $\boldsymbol{\gamma}$. gl 31.8\%), TTT 1.6U, ZTT $19.2 \mathrm{U}$, T-Bil $0.4 \mathrm{mg} /$ $\mathrm{dl}$, GOT $27 \mathrm{IU}, \mathrm{GPT} 13 \mathrm{IU}$, Che $0.66 \mathrm{k} \triangle \mathrm{ph}$, Alp 6.8 KAU, $\gamma$-GTP $19 \mathrm{mu} / \mathrm{ml}$, LDH 337 WU, FBS $90 \mathrm{mg} / \mathrm{dl}$, $50 \mathrm{~g}$ OGTT 正常型, HB ag (-), $\mathrm{HBab}(-)$, AFP $58.4 \mathrm{ng} / \mathrm{ml}$, CEA 3.1ng/ml, ICG Rmax $2 \mathrm{mg} / \mathrm{kg} / \mathrm{min}$, であった。

総肝動脈造影像上, 右後区域枝の末梢に血管の増生 之腫堭濃染像があり, 右後上亜区域にも娘結節が認め られ, 経動脈性門脈造影像では門脈右後枝の描出が不 明暸であった（図 4 ).PTPを行うと，右後下枝はその 血流量の減少のためか遅れて造影され，その分枝に先 細りの閉塞像があり, sinusoidal phaseでは腫瘍に一 致して陰影欠損が認められた。右 2 区域切除が施行さ れたところ,門脈右後下枝の閉塞は腫瘍塞栓ではなく,
腫瘍の圧迫によることが明らかとなった（図５）。 症例 4.46歳, 男, 材木業,

慢性肝炎で加療中, 肝シンチ検查で肝右葉に focal defectを指摘され，精查目的で当科に入院した。肝を 正中線上 3 横指, 右鎖骨中線上で 4 横指触知した。 入 院時の血液化学検查では, WBC $7.900 / \mathrm{mm}^{3}, \mathrm{RBC}$ $490 \times 10^{4} / \mathrm{mm}^{3}, \mathrm{Hb} 16 \mathrm{~g} / \mathrm{dl}, \mathrm{Ht} 48.4 \%$, 血小板 $16.4 \times$ $10^{4} / \mathrm{mm}^{3}$, 出血時間 3 分, 凝固時間 9 分, Prothrombin time $61 \%$, Hepaplastin test $76 \%$, TP $6.7 \mathrm{~g} / \mathrm{dl}$ (Alb $3.9 \mathrm{~g} / \mathrm{dl}, \gamma$-gl $17.5 \%$ ), TTT $5.3 \mathrm{U}$, ZTT $8.3 \mathrm{U}, \mathrm{T}$. Bil $0.7 \mathrm{mg} / \mathrm{dl}$, GOT 125IU, GPT 131IU, Che $0.61 \triangle$ ph, HBag (-), HBab (-), AFP $151 \mathrm{ng} / \mathrm{ml}$, ICG $\mathrm{Rmax} 2.0 \mathrm{mg} / \mathrm{kg} / \mathrm{min}$ であった。

腹腔動脈造影像では右後区域枝の末梢に腫煌血管と 腫瘍濃染像を認め, 経動脈性門脈造影像では右後枝の 分岐異常が疑われ，腫瘍付近の門脈像は不鮮明であっ た. PTPを行ったところ, 右後枝の分岐異常と右尾状 葉枝が確認されたのみならず右後上枝内に陰影欠損が 認められた. 右 2 区域切除を施したところ, 右後上枝 は腫瘍塞栓で閉塞されていた（図 6).

\section{IV 考 察}

最近に新ける各種画像診断の開発・普及により原発 性肝癌は比較的早期に診断され, これに対して肝切除 が積極的に行われるようになり，今後治療成績の向上 が期待される. しかし, 細小肝癌でも術後早期に再発 を来たしたり，また逆に比較的大きな肝癌でも予後の 良好なるのがあるなど, 癌の大きさだけでその予後を 推定するのは困難である。

ところで肝癌が門脈内腫瘍塞栓を形成することはよ く知られた事実であり, その頻度について Edmondson ${ }^{5}$ は $33.8 \%$ と報告している.一方, 最近の報 告によると奥田 ${ }^{6}$ は $77.2 \%$, 桑尾 ${ }^{7)} 90.2 \%$, 岡崎8 $74 \%$ と のべ, 肝癌では門脈内腫瑒塞栓が高頻度に発生するこ とを裹書きしている。すちろんこれらの頻度は剖検時 あるい惟行した肝癌に招けるものであり，外科臨床 で取り扱う比較的小さな肝癌ではその頻度が当然低い と考穴られる。しかし岡崎ら ${ }^{81}$ は, 肝内門脈枝の 1 次, 2 次分枝の腫瘍塞栓の存在が予後ときわめて密接に関 係することを示し, 門脈内腫瘍塞栓が肝内転移へと進 展する一つの仮説を想定している，肝癌におけるこの 肝内発育様式を考慮すると, 門脈内腫瘍塞栓の存在は 肝癌の手術適応の決定や予後の推定にきわめて重要な 因子になると考光られる。

さて, 原発性肝癌に扣ける門脈内腫瘍塞栓の猃断方 
図 5 症例 3 の血管造影像と切除標本

A. 造影剂注入 1 秒後の PTP：右後下亜区域枝の造影が不充分である。

B. 2 秒後の PTP：後下亜区域枝の末梢に先細りの閉塞像（矢印）がみられる。

C. PTP sinusoidal phase：腫場部に一致して filling defect（矢印）を認める.

D. 切除標本：右後下枝の閉塞は腫場による単なる圧迫閉塞であった。

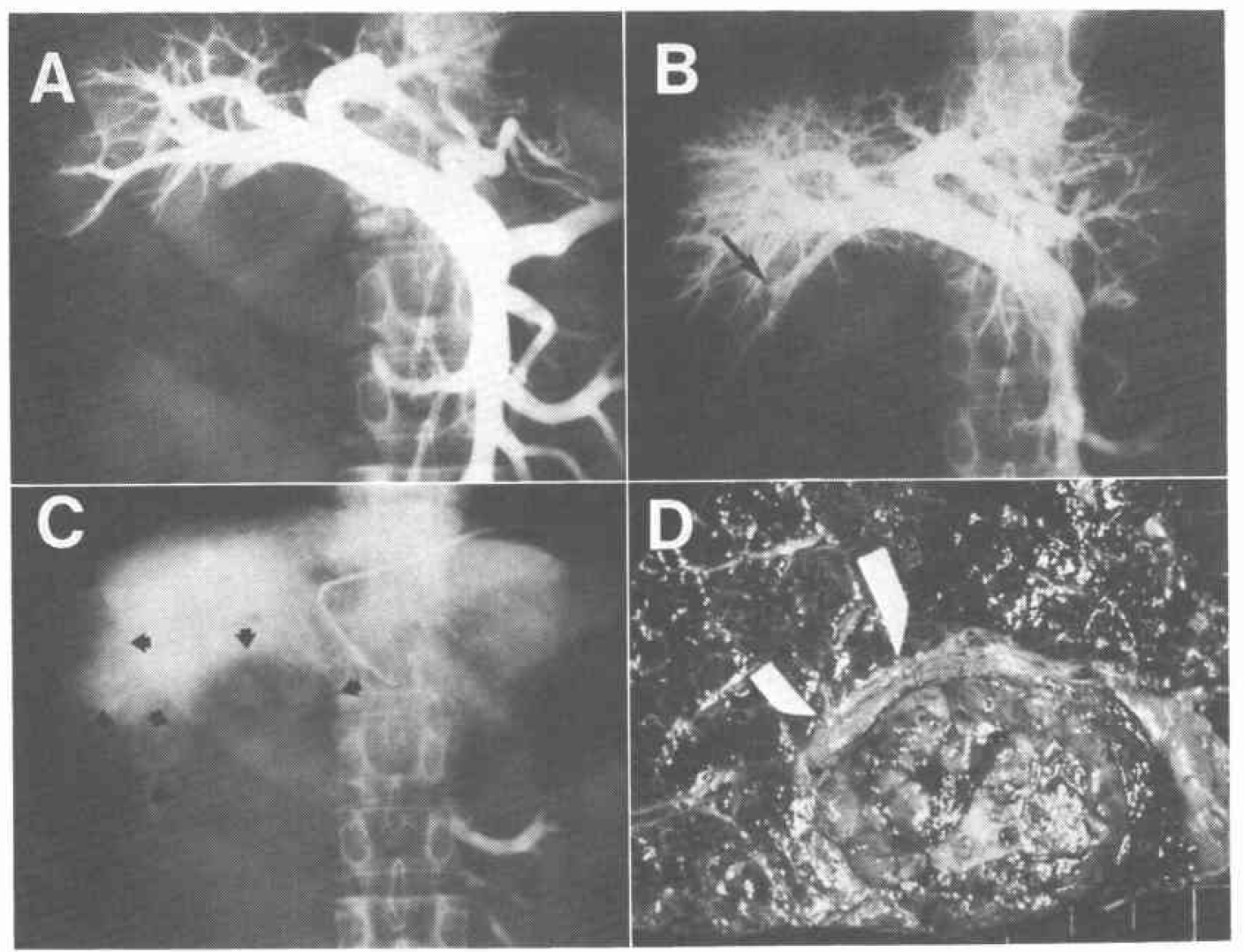

法には現在血管造影法 ${ }^{9)}, \mathrm{CT}^{10)}$ ，超音波検查 ${ }^{11}$ などが ある。奥田 $ら^{6}$ ( celiac angiogram 上の thread and streaks signs に注 目すべきであると述べているが，この signがみられた 9 症例はすでに腹水の貯留した進行肝癌例であった。 また最近開発された CT angiography ${ }^{12}$ 柱閉塞門脈枝 の有無を発見するのに有用であるが，腫埸塞栓のある 門脈枝を含めた脈管構築全体を把握するのは困難であ る.したがって，外科治療の対象となる比較的早期の 肝癌における閉塞門脈枝の存在とその部位診断を行う には，門脈造影加術中超音波検査 ${ }^{13)}$ を行う以外に方法 はないと考觉る。しかしこれまでの経動脈性門脈造影 法では自験例のように門脈幹および 1 次分枝の読影が その限界であり，肝内門脈枝の読影は不可能なことが 多い. 最近岡崎ら ${ }^{8}$ は, カテーテルの先端を下荤十二指
腸動脈の起始部より更に末梢側の上腸間膜動脈内に插 入し，門脈内に流入する造影剂を増量，造影して門脈 像のコントラストを増加させるよう工夫しているが， 門脈右枝では 2 次分枝, 左枝では 1 次分枝がその読影 の限界と考えられる、そこで著者らは荤胆道系悪性腫

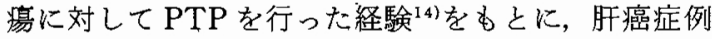
にも超音波誘導下に門脈脐部あるいは門脈右枝を穿刺 し，PTPを試みたわけである。もちろん経肝的門脈穿

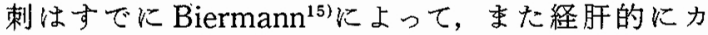
テーテルを門脈内に挿入する手技は Lunderquist ${ }^{16)} ら$ によってそれぞれ報告されささらに Aransen ${ }^{17)}$, Hoevels ${ }^{18)}$ はすでに肝癌例に対してもPTPを行って いる、しかし Hoevels の目的は PTP の診断的意義を 肝動脈造影法と比較したにすぎず, PTPの診断的意義 に関してむしろ否定的な見解を述べている。しかし， 
図 6 症例 4 の血管造影像と切除標本

A. 腹腔動脈造影像：右後枝の末梢に腫湯血管を認める.

B. 動脈性門脈造影像：門脈右枝の分岐異常（矢印）が疑われる.

C. PTP：門脈右後枝の分岐異常が明らかになり，右尾状葉枝（小知印）と右 3 次分 枝内の陰影欠損 (大矢印) が認められる。

D. 切除標本：右後枝 3 次分枝内に腫瘍塞栓（矢印）が認められる.

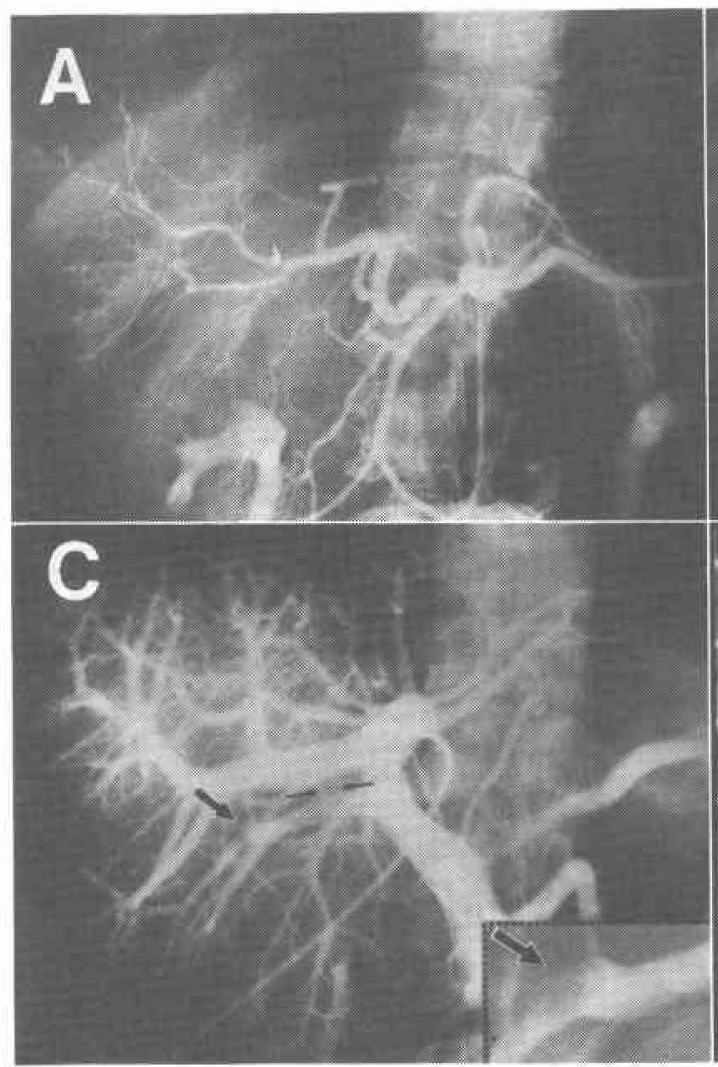

著者らがPTPを行った主目的は肝癌の存在診断では なく，担癌門脈枝の同定と門脈内腫瘍塞栓の診断，ひ いてはその手術適応を決めることであった。 その結果, 原発性肝癌12例に拈けるPTP 所見をみると, 肝内 門脈枝の閉塞 7 例, 王排 5 例, 門脈内陰影欠損 3 例が 描出された。また 2 例の陰影欠損像は腫瘍塞栓である ことが，また 7 例にみられた先細りの閉塞は腫瘍によ る単なる王迫閉塞であることが切除標本で明らかに なった.さらに右後枝の分岐異常が12例中 3 例 (25\%), 尾状葉枝の分枝が 10 例 (83\%) に確認され，これらの 正確な情報が肝門部剥離操作上に役立つことも判明し た(表 3). 一方, 超音波検査法も腫瘍と肝脈管構築と の関係を把握するのにすぐれた検査法 ${ }^{19)}$ であ.とく に幕内ら ${ }^{20}$ によって最近開発された術中超音波検查用 探触子を用いると, 腫瘍の流入・流出血管を描出でき

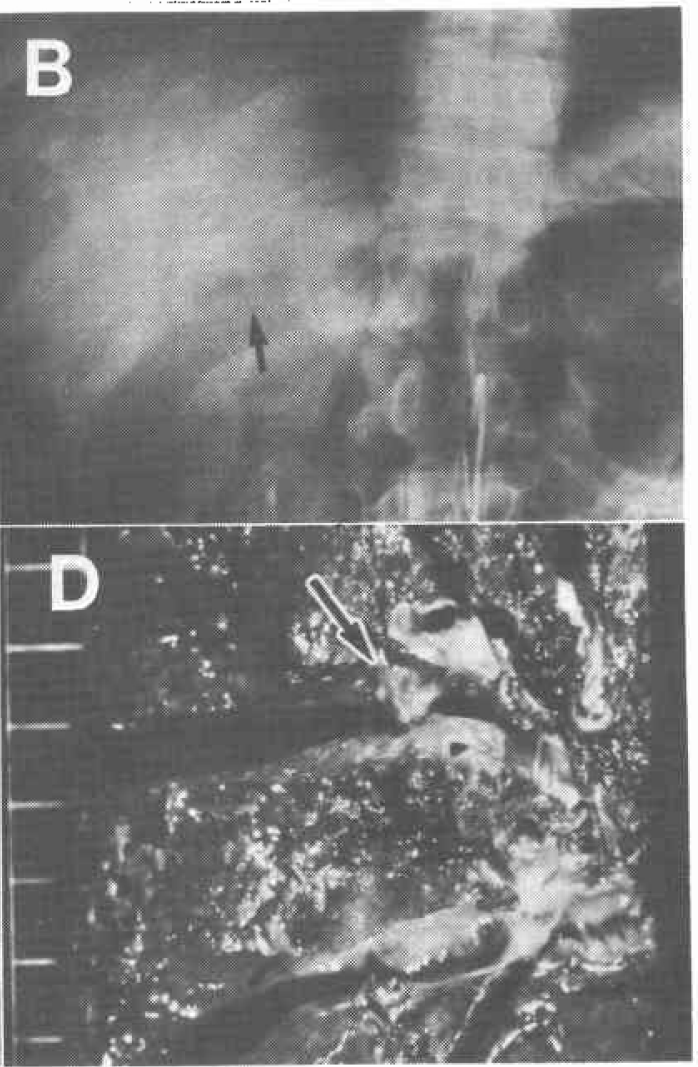

るため,これら血管内の腫瘍塞栓の診断も可能であり， また肝硬変合併肝癌に対する亜区域切除にきわめて有 用である. しかし幕内ら ${ }^{13)}$ も指摘しているように超音 波検查で門脈枝の確認できない症例では，その閉塞が 腫瘍による压迫か，腫瘍塞栓によるものか判定でさな い.この点著者らが行った超音波下 PTP は閉塞部を 鮮明に描出するため, 両者の鑑別が比較的容易である。 すなわち腫瘍による単なる王追閉塞は症例 3 に示した

表 3 超音波下 PTP の利点

\begin{tabular}{ll}
\hline \hline 1. & 肝内門脈枝の腫浧塞栓の診断 \\
2. & 亜区域切除におりる切除門脈枝の決定 \\
3. & 門脈側副血行路の確認 \\
4. & 門脈分岐状態や尾状葉枝の確認により肝門部剥離 \\
& 操作に有用である
\end{tabular}


ようにPTP 上先細りの閉塞像を示し, 腫汮塞栓では 症例 4 のように陰影欠損として描出されるのである. したがってPTPは術中超音波検査法とともに，門脈 内腫瘍塞检の診断に役立ち, ひいてはその病態を重視 した肝癌の手術とくに肝硬変合併肝癌に対寸る覀区域 切除にきわめて確実な情報を提供すると考克られる。

\section{$\mathbf{V}$ 結 語}

原発性肝癌の術前に超音波誘導下 PTP を施行し， その造影所見を検討した結果, 門脈枝内腫煌塞栓の診 断, 亜区域切除における切除門脈枝の決定, 側副血行 路の確認, 門脈分枝状態, 尾状葉枝の確認などにより, 肝癌の手術適応ならびに肝門部剝離操作に有力な情報 を提供すると考えられる。

なお本論文の要旨は第19回日本消化器外科学会総会に扔い て発表した。

\section{文献}

1）山崎 晋, 長谷川博, 幕内雅敏：細小肝癌の臨床病 理学的分析々, それにもとづく新しい概念の切除 法一27切除例の検討一, 肝喴 $22: 1714-1723$, 1981

2）日本肝癌研究会：原発性肝癌症例に関する追跡調 査一第 4 報一。肝荗 $20: 433-441 ， 1979$

3）幕内雅敏, 長谷川博, 山崎 晋：術中超音波検查. 日外会誌 $82 ： 1094-1098,1981$

4）玉岡紅一, 山田龍作, 中塚春樹ほか：血管カテーテ ル術の治療への応用. 2, 経皮経肝食道静脈瘤塞栓 術. Medical Postgraduates 19:167-174, 1981

5) Edmondson HA, Steiner PE: Primary carcinoma of the liver. A study of 100 cases among 48,900 necropsies. Cancer 7:462-503, 1954

6）奥田邦雄, 武者厷隆, 吉田孝宣はか：Celiac Angiographyによる肝細胞癌の門脈内発育の診断, ことに Thread and streaks sign について. 臨放 線 $21: 765-771,1976$

7) 桑尾定明：原発性肝癌の病理形態学的研究. 肝細 胞癌の肝内血管系に打ける腫煌血栓について。肝 葴 $20: 828-838,1979$

8）岡崎正敏, 森山紀之, 山田達哉洁：肝癌の血管造 影門脈所見の意義。門脈所見からみた手術適応な らびに予後との関係. 日消病会誌 $77: 758-767$, 1980
9）市原荘六, 杉浦光雄, 島 文夫：肝疾患の診断一肝 血管造影一。外科診療 $19: 19-30,1978$

10) Vigo M, Faveri DD, Biondetti PR et al.: CT demonstruation of portal and superior mesenteric vein thrombosis in hepatocellular carcinoma. J Comput Assist Tomogr 4: $627-629,1980$

11）野口武英，木村邦夫, 大藤正雄ほか：肝細胞癌にお ける門脈内腫演塞栓の超音波診断。肝葴 21 : 496, 1980

12) Freeny PC: Portal vein tumor thrombus; Demonstruation by computed tomographic arteriography. J Comput Assist Tomogr 4 : $263-264,1980$

13）幕内雅敏, 長谷川博, 山崎 晋：訮の術中超音波検 查一特に最近の亜区域切除について，外科治療 $44: 579-586,1981$

14）木下博明, 酒井克治, 津田勇平注か：膵・胆道系悪 性腫湯の外科治療に打㳗皮経肝門脈造影の診 断的意義. 消外 $3: 91-96,1980$

15) Biermann HR, Byron RL, Kelly KH : Portal vein puncture. A percutaneous trans-hepatic approach. Proc Soc Exp Biol Med 79: $550-552,1952$

16) Lunderquist A, Vang J: Transhepatic catheterization and obliteration of the coronary vein in patients with portal hypertention and esophageal varices. N Engl J Med 291: $646-649,1974$

17) Aronsen KF, Lunderquist A, Nylander G: The comparison of celiacography and direct portography in the diagnostic evaluation of liver diseases. Radiology $92: 313-322,1969$

18) Hoevels $\mathrm{J}$ : Malignant lesions of the liver-A comparative stuidy using infusion hepatic angiography and percutaneous transhepatic portography (PTP). European Society of Cardiovascular Radiology 23:376-378, 1979

19）秋本 伸：腹部ェコー法の現況一肝癌. Medicina $18: 1146-1149,1981$

20）幕内雅敏, 長谷川博, 山崎 晋ほか：新たに開発し た術中超音波検査内探触子, 映像情報 11 ： 1167-1169, 1979 